\title{
Effect of Foliar and Soil Application of Potassium Fertilizer on Soybean Seed Protein, Oil, Fatty Acids, and Minerals*
}

\author{
Manju Pande1\#, Mudlagiri B. Goli' ${ }^{1}$, Nacer Bellaloui2 \\ ${ }^{1}$ Department of Natural Sciences and Environmental Health, Mississippi Valley State University, Itta Bena, USA \\ ${ }^{2}$ Crop Genetics Research Unit, United States Department of Agriculture, Agricultural Research Service, \\ Stoneville, USA \\ Email: ${ }^{\#}$ mpande7@gmail.com
}

Received 17 December 2013; revised 28 January 2014; accepted 19 February 2014

Copyright @ 2014 by authors and Scientific Research Publishing Inc.

This work is licensed under the Creative Commons Attribution International License (CC BY).

http://creativecommons.org/licenses/by/4.0/

(c) (i) Open Access

\section{Abstract}

The objective of this research was to evaluate the effectiveness of soil and foliar application of potassium (K) on leaf and seed mineral concentration levels, and seed composition (protein, oil, fatty acids, and minerals). Soybean cultivar (Pioneer 95470) of maturity group 5.7 was grown in a repeated greenhouse experiment in a randomized complete block design. Treatment consisted of two concentrations of foliar $K$ application ( $\mathrm{T} 1$, rate of $1.75 \%$ and $\mathrm{T} 2$, rate of $2.5 \%$ ) and soil application (T3, rate of $190 \mathrm{mg} / \mathrm{kg}$ and T4, rate of $380 \mathrm{mg} / \mathrm{kg})$. Potassium was applied for each type at V3 (vegetative) and R3 (beginning of seed pod initiation) stages. The results showed higher $\mathrm{K}$ and $S$ concentrations in leaves in $\mathrm{T} 1$ and $\mathrm{T} 2$. The concentrations of $\mathrm{B}$ and $\mathrm{Zn}$ decreased in all treatments, whereas Fe concentration increased in $\mathrm{T} 1$ and $\mathrm{T} 3$. In seeds, most mineral concentrations were stable, except for Fe which increased in both $\mathrm{T} 1$ and $\mathrm{T} 3$. Seed protein percentage increased $3.0 \%$ in $\mathrm{T} 3$ compared with the control (no $\mathrm{K}$ application). Seed oil percentage showed a general decrease in all the treatments, except for $3.2 \%$ increase in T4. Palmitic acid percentages showed significant increase in all concentrations, the highest percentage increase of $16.9 \%$ was observed in T4. Stearic acid increased in T2 and T3. Linoleic acid percentages increased in both foliar treatments, but linolenic acid percentage increased in high soil treatment $\mathrm{T} 4$ alone, with an increase of $\mathbf{1 2 . 2 \%}$ in comparison to the control. Significant decrease $(\mathbf{1 5 . 8 \% )}$ in linoleic acid was found in foliar application, T2. Oleic acid decreased uniformly in all treatments, where the highest decrease (19.2\%) was observed in soil application, T4. Our research demonstrated that both foliar and soil application of $K$ were found to selectively alter seed composition. Further research is needed to be conducted under field conditions before conclusions can be made.

\footnotetext{
"Mention of trade names or commercial products in this publication is solely for the purpose of providing specific information and does not imply recommendation or endorsement by the U.S. Department of Agriculture.

"Corresponding author.
}

How to cite this paper: Pande, M., Goli, M.B. and Bellaloui, N. (2014) Effect of Foliar and Soil Application of Potassium Fertilizer on Soybean Seed Protein, Oil, Fatty Acids, and Minerals. American Journal of Plant Sciences, 5, 541-548. 


\section{Keywords}

\section{Potassium; Soybean; Seed Minerals; Seed Composition; Foliar Application}

\section{Introduction}

Soybean is the second largest crop in cash sales. The majority of soybean crops are processed for oil and meal, and soybean is the only plant food that contains complete protein that provides all essential amino acids required for human health. Soybean seed also contains carbohydrate, fatty acids, and minerals [1]. Polyunsaturated fatty acids in diet have been shown to actively lower serum cholesterol levels [2]. Soybean oil is rich in polyunsaturated fatty acids, including the two essential fatty acids, linoleic and linolenic, that are not produced in the body. Linoleic and linolenic acids help the absorption of vital nutrients required for human health [1], and soy products have also been shown to be useful in prevention and treatment in bone resorption, inhibiting ovarian, breast and colon cancer, and other chronic heart and kidney diseases [3]-[9].

Potassium (K) is an essential nutrient involved in regulating water balance [10] and enhancing water uptake. Potassium is involved in nearly all processes needed to sustain plant life [11] besides its role in conferring pest and disease resistance. Soybean crop takes up and removes large amounts of potassium from soil than any other nutrient [11]. Potassium application have shown to increase the number of pods as well as exerted a beneficial influence on retaining pods until harvest in soybean [12]. Potassium fertilization can be either applied to soil or as foliar spray to plants. Soil application is the standard form of application and has its own advantages unless soil $\mathrm{pH}$ and other factors affect the movement and uptake from soil to the plants. Foliar application can rapidly help plants to recover from stress due to drought, high heat, pests and diseases. The conventional way [13] [14] to apply $\mathrm{K}$ to the soil is before planting (pre-planting), and larger quantity may improve soil fertility for subsequent crops. Previous research has focused on foliar fertilization of soybeans at late reproductive stages and produced inconsistent and insignificant results [15] [16]. However, foliar application is still attracting researchers' interest [16]-[18] to evaluate effective rates and timing of application to avoid drought and heat stress at critical stages. Studies [13] have shown that both pre-plant and foliar K applications can increase soybean yields with low to medium soil $\mathrm{K}$ levels. Although foliar and soil application of $\mathrm{K}$ fertilizers have been used to maintain optimum level of nutrients [18] in crop, there is limited information on the effect of foliar and soil K fertilizer on seed composition (protein, oil, fatty acids, and minerals). The objective of this research was to investigate the effectiveness of foliar and soil applications of $\mathrm{K}$ fertilizer on soybean seed protein, oil, fatty acids, and minerals.

\section{Materials and Methods}

\subsection{Experimental Design, Statistical Analysis, and Treatment}

A greenhouse experiment was conducted twice at Mississippi Valley State University. Soybean cultivar Pioneer 95 Y70 of maturity group 5.7 was grown and 4 replicates were used. The experimental design was a randomized block. Statistical analyses were performed using ANOVA in SAS. Level of significance was at $\mathrm{P} \leq 0.05$. The soil used for this experiment was Earthgrow top soil, the soil physical and chemical properties were as follows: Soil texture was of sandy clay, $\mathrm{pH}$ 6.34. Base saturation of the soil was 95.13, and organic matter (OM\%) was 36.92. Macro- and micro-nutrient concentrations in soil were (mg/kg): N (170), S (170), P (20.2), Ca (3307), K (351), Mg (201), Cu (0.48), Fe (65), Mn (84), Zn (6.54), Na (80.8). The greenhouse is located in Itta Bena, Mississippi with latitude of $\mathrm{N} 33^{\circ} 28^{\prime}$ and longitude $\mathrm{W} 90^{\circ} 20^{\prime}$. The experiment was carried out, starting in May until end of September (seed maturity stage). The temperature ranged from $24.4^{\circ} \mathrm{C}$ in early May to $35^{\circ} \mathrm{C}$ in July and August. The treatments consisted of control (C, no K application), two concentrations of foliar K application (T1 $=\mathrm{K}_{2} \mathrm{SO}_{4}$ at the rate of $1.75 \%$; and $\mathrm{T} 2=\mathrm{K}_{2} \mathrm{SO}_{4}$ at rate of 2.5\%), and two concentrations of soil application ( $\mathrm{T} 3=$ $\mathrm{K}_{2} \mathrm{SO}_{4}$ at the rate of $190 \mathrm{mg} / \mathrm{kg}$; and $\mathrm{T} 4=\mathrm{K}_{2} \mathrm{SO}_{4}$ at the rate of $380 \mathrm{mg} / \mathrm{kg}$. Potassium was applied at vegetative (V3) and beginning of seed pod initiation (R3) stages.

\subsection{Leaf and Seed Mineral Analysis}

Leaf tissue samples were collected one week after the second application, dried and analyzed for mineral con- 
centration. Similarly seeds were harvested and collected at maturity for seed mineral analysis. Leaf and seed mineral analysis was done at the Soil, Plant and Water laboratory at the University of Georgia, Athens, GA. Briefly, nutrients were analyzed by digesting $0.5 \mathrm{~g}$ of ground seed in $\mathrm{HNO}_{3}$ in a microwave digestion system. Nutrients were determined using ICP. The total $\mathrm{N}$ was measured in a 0.25 -g sample using an elemental analyzer.

\subsection{Seed Protein, Oil, and Fatty Acid Analysis}

Soybean seeds were harvested at maturity and analyzed for protein, oil and fatty acids using infra-red (NIR) instrument at USDA-ARS in Stoneville, MS. Briefly, about $25 \mathrm{~g}$ of whole seed from each treatment was analyzed by near infrared reflectance [19] using a diode array feed analyzer AD 7200 (Perten, Springfield, IL). Calibrations were developed by the University of Minnesota, using Perten's Thermo Galactic Grams PLS IQ software, and the calibration curve was established according to AOAC methods [20] [21]. Protein and oil analyses were conducted based on a seed dry matter basis [19] [22], and fatty acids were analyzed on an oil basis.

\section{Results}

\subsection{Leaf Mineral Concentrations}

Potassium concentration in leaves was high in all treatments, and the highest percentage of $\mathrm{K}(2.75 \%)$ was observed at the higher rate of foliar application (T2) compared to control (1.90\%) (Table 1). Nitrogen concentration was also high in K foliar applications (T1) and K soil application (T3). Leaf S concentration increased in both foliar treatments T1 $(0.31 \%)$ and T2 $(0.33 \%)$ compared to control $(0.14 \%)$. Leaf B and Zn concentrations decreased in all four $\mathrm{K}$ treatments, and the lowest concentrations of $\mathrm{B}$ was in $\mathrm{T} 1(66.2 \mathrm{mg} / \mathrm{kg})$ and lowest $\mathrm{Zn}$ in T4 (50.1 mg/kg) compared to B control (82.3 mg/kg) and Zn control (59.1 mg/kg), respectively. Whereas, Fe increased in both lower concentrations of foliar (T1) and Soil (T3) treated plants. Concentration of Na significantly increased in leaves of both foliar treatments T1 $(351.25 \mathrm{mg} / \mathrm{kg})$ and T2 $(494.83 \mathrm{mg} / \mathrm{kg})$ compared to control $(36.83 \mathrm{mg} / \mathrm{kg})$.

\subsection{Seed Mineral Concentrations}

Seed K concentration remained stable (Table 2) in foliar applications, but decreased in soil applications compared to control. Seed N concentration (Table 2) showed positive response in T2 (6.4\%) and T3 (6.4\%) compared to control (6.2\%). Unlike in leaf tissue, $\mathrm{S}$ concentration in seeds decreased in both foliar and soil application at lower rate K. Seed B concentration in leaf tissue decreased in foliar applications but remained constant with soil treatments. Zn was more stable in seeds, increasing only in low rate of foliar K treatment $(77.6 \mathrm{mg} / \mathrm{kg})$ compared to control (71.92 mg/kg). Fe concentration increased in seeds in all treatments compared to control. Na concentration was found to be generally higher in control $(639.4 \mathrm{mg} / \mathrm{kg})$ compared to leaf tissue concentration in fertilized plants ( $36.83 \mathrm{mg} / \mathrm{kg}$ ). However, in contrast to the trend seen in leaves, Na concentration in seed decreased in all treatments compared to control.

Table 1. Mean values of leaf mineral concentration in RR soybean pioneer 95Y70 as affected by foliar and soil application of K fertilizer.

\begin{tabular}{|c|c|c|c|c|c|c|c|}
\hline \multirow{2}{*}{ Treatment } & \multicolumn{3}{|c|}{ Macronutrients (\%) } & \multicolumn{4}{|c|}{ Micronutrients (mg/kg) } \\
\hline & $\mathrm{K}$ & $\mathrm{N}$ & $\mathrm{S}$ & B & $\mathrm{Fe}$ & $\mathrm{Zn}$ & $\mathrm{Na}$ \\
\hline Control & $1.90 \mathrm{c}$ & $2.27 \mathrm{~b}$ & $0.14 \mathrm{c}$ & $82.26 a$ & $76.89 b$ & 59.10a & $36.83 c$ \\
\hline $\begin{array}{c}\text { T1-Foliar } \\
\text { 1.75\% }\end{array}$ & $2.50 \mathrm{~b}$ & 2.63a & $0.31 b$ & $66.17 \mathrm{C}$ & $85.26 \mathrm{a}$ & $52.49 b$ & $351.25 b$ \\
\hline $\begin{array}{c}\text { T2-Foliar } \\
2.5 \%\end{array}$ & $2.75 a$ & $2.21 b$ & $0.33 a$ & $74.18 \mathrm{~b}$ & $70.42 b$ & $52.00 \mathrm{~b}$ & 494.83a \\
\hline Control & $1.90 \mathrm{~b}$ & $2.27 b$ & $0.14 b$ & $82.26 a$ & $76.87 b$ & $59.10 \mathrm{a}$ & 36.83a \\
\hline $\begin{array}{c}\text { T3-Soil } \\
190 \text { mg/kg }\end{array}$ & $2.07 a$ & $2.95 a$ & $0.15 \mathrm{ab}$ & $68.92 c$ & $84.53 a$ & $56.18 b$ & $29.36 b$ \\
\hline $\begin{array}{c}\text { T4-Soil } \\
380 \text { mg/Kg }\end{array}$ & $1.90 \mathrm{~b}$ & $2.25 b$ & $0.16 \mathrm{a}$ & $73.68 \mathrm{~b}$ & $76.83 b$ & $50.08 \mathrm{c}$ & $20.28 c$ \\
\hline
\end{tabular}

Notes: Means (4 rep) within a column between treatment groups, followed by the same letter are not significantly different at $\mathrm{P} \leq 0.05$ level. 
Table 2. Mean values of seed mineral concentration in RR soybean pioneer 95Y70 as affected by foliar and soil application of K fertilizer.

\begin{tabular}{|c|c|c|c|c|c|c|c|}
\hline \multirow{2}{*}{ Treatment } & \multicolumn{3}{|c|}{ Macronutrients (\%) } & \multicolumn{4}{|c|}{ Micronutrients (mg/kg) } \\
\hline & $\mathrm{K}$ & $\mathrm{N}$ & $\mathrm{S}$ & B & $\mathrm{Fe}$ & $\mathrm{Zn}$ & $\mathrm{Na}$ \\
\hline Control & $2.31 \mathrm{a}$ & $6.22 b$ & $0.33 a$ & $39.82 \mathrm{a}$ & $86.75 b$ & $71.92 b$ & $639 a$ \\
\hline $\begin{array}{c}\text { T1-Foliar } \\
1.75 \%\end{array}$ & $2.36 \mathrm{a}$ & $6.24 \mathrm{ab}$ & $0.32 \mathrm{a}$ & 38.41a & $90.48 a$ & 77.66a & $484 b$ \\
\hline $\begin{array}{c}\text { T2-Foliar } \\
2.5 \%\end{array}$ & $2.35 a$ & $6.35 a$ & $0.32 \mathrm{a}$ & $35.82 b$ & 88.68ab & $71.22 \mathrm{~b}$ & $516 b$ \\
\hline Control & $2.31 \mathrm{a}$ & $6.22 b$ & $0.33 a$ & $39.82 \mathrm{a}$ & $86.75 b$ & $71.92 \mathrm{a}$ & $639 a$ \\
\hline $\begin{array}{c}\text { T3-Soil } \\
190 \text { mg/kg }\end{array}$ & $2.25 b$ & $6.40 \mathrm{a}$ & $0.31 \mathrm{a}$ & $39.62 \mathrm{a}$ & 89.61b & $70.44 \mathrm{ab}$ & $534 b$ \\
\hline $\begin{array}{c}\text { T4-Soil } \\
380 \text { mg/Kg }\end{array}$ & $2.21 \mathrm{~b}$ & $6.20 \mathrm{~b}$ & $0.32 \mathrm{a}$ & $38.92 \mathrm{a}$ & $103 a$ & $69.58 b$ & $483 b$ \\
\hline
\end{tabular}

Notes: Means (4 rep) within a column between treatment groups, followed by the same letter are not significantly different at $\mathrm{P} \leq 0.05$ level.

\subsection{Seed Composition}

Results from the repeated experiments were combined as no significant interactions were found between the two experiments for seed composition constituents. Protein percentage significantly increased (3.03\%) with T3 soil application, but only slightly increased in T1 (1.72\%) and T2 (1.24\%) compared to control (Table 3). Protein percentage (Table 3 ) however slightly decreased with soil treatment T4 (0.57\%). No change was observed in oil percentages in T1, with a slight decrease of $0.20 \%$ in T2, whereas a significant decrease (5.19\%) was found in soil application (T3) compared to control. Oil percentage, on the other hand, increased (3.19\%) in soil application T4. Linoleic percentages in seeds increased in both foliar applications with an increase of $1.98 \%$ in T1 and $3.33 \%$ in $\mathrm{T} 2$ while it remained relatively stable with soil applications. Linolenic acid decreased with foliar treatment while it increased with soil applications. Oleic acid percentages in the seeds decreased in all treatments, and the greatest decrease (19.24\%) was found in soil treatment T4 (Table 3).

\section{Discussion}

\subsection{Leaf and Seed Mineral Concentration}

Results showed that leaf and seed mineral concentrations were affected by both foliar and soil application of K. Lower rates of foliar (T1), and soil (T3) applications showed higher concentrations of K, N, and Fe in leaf tissue, with the highest increase of these nutrients found in foliar treatments. Previous studies [11] [23]-[25] reported increased accumulation of $\mathrm{N}, \mathrm{P}, \mathrm{K}$, and micronutrients in soybean tissues when $\mathrm{K}$ fertilizer was applied. In the present study, some of nutrients in seeds responded differently than in the leaves. For example, in seeds, K remained constant with foliar treatment while it slightly decreased with soil applications compared to control. $\mathrm{N}$ increased in T2 and T3 alone in seeds, while in leaves N increased in T1 and T3. Fe responded by increasing in seeds with all $\mathrm{K}$ applications while Fe increased only in $\mathrm{T} 1$ and $\mathrm{T} 3$ in leaves, demonstrating inconsistent results between leaf and seed minerals. The increase in mineral concentrations in leaf tissue did not necessarily result in increases in seed concentrations, and this may be due to translocation and uptake mechanism differences for minerals or due to mineral requirement differences by seed. Recently [26], it was reported that K concentration in leaves and seeds increased with $\mathrm{K}$ application rate increase, although the increase of $\mathrm{K}$ was not found to be consistent by year and location in some cases. Also, it was reported that $\mathrm{K}$ application resulted in higher yield [11] [23]. The significantly higher $\mathrm{Na}^{2+}$ concentrations in foliar treated soybean leaves compared with control and soil applications were previously reported. For example, it was reported that plants had higher salt index when treated with foliar K [27], and plants that had leaf burn and decreased yield had high salt index [28]. In the present study, we did not observe any visible damage or leaf burn, and seeds actually had lower Na concentrations in treated groups compared to control, suggesting that the rates of $\mathrm{K}$ applied in this experiment were not at toxic levels. In spite of this, salt injury in plant tissue needs to be investigated further. It was reported that using fluid products with low salt index [14] [29] [30] or using small amounts of nutrient sprayed onto soybean foliage at early stages when soil conditions limit nutrient uptake could minimize salt accumulation. 
Table 3. Mean values of seed protein, oil and fatty acid percentages in Pioneer 95Y70 as affected by foliar and soil application of K fertilizer.

\begin{tabular}{|c|c|c|c|c|c|c|c|}
\hline Treatment & Protein & Oil & Palmitic & Stearic & Oleic & Linoleic & Linolenic \\
\hline control & 41.93bc & 18.76a & $10.38 b$ & $4.25 b$ & $22.41 \mathrm{a}$ & 55.50c & $7.66 a$ \\
\hline $\begin{array}{c}\text { T1-Foliar } \\
\text { 1.75\% }\end{array}$ & $\begin{array}{c}42.65 \mathrm{ab} \\
(+1.72)\end{array}$ & 18.76a & $\begin{array}{c}10.41 b \\
(+0.36)\end{array}$ & $4.25 b$ & $\begin{array}{c}21.1 b \\
(-5.58)\end{array}$ & $\begin{array}{c}56.60 \mathrm{~b} \\
(+1.98)\end{array}$ & $\begin{array}{c}7.13 \mathrm{a} \\
(-7.01)\end{array}$ \\
\hline $\begin{array}{c}\text { T2-Foliar } \\
2.5 \%\end{array}$ & $\begin{array}{c}42.45 \mathrm{ab} \\
(+1.24)\end{array}$ & $\begin{array}{c}18.73 a \\
(-0.20)\end{array}$ & $\begin{array}{l}11.15 a \\
(+7.47)\end{array}$ & $\begin{array}{c}4.49 \mathrm{a} \\
(+5.58)\end{array}$ & $\begin{array}{l}20.35 b \\
(-9.20)\end{array}$ & $\begin{array}{c}57.35 a \\
(+3.33)\end{array}$ & $\begin{array}{c}6.45 b \\
(-15.82)\end{array}$ \\
\hline control & 41.93bc & $18.76 b$ & $10.38 c$ & $4.25 b$ & $22.41 \mathrm{a}$ & $55.50 \mathrm{a}$ & $7.66 \mathrm{~b}$ \\
\hline $\begin{array}{c}\text { T3-Soil } \\
190 \mathrm{mg} / \mathrm{kg}\end{array}$ & $\begin{array}{l}43.20 \mathrm{a} \\
(+3.03)\end{array}$ & $\begin{array}{c}17.79 c \\
(-5.20)\end{array}$ & $\begin{array}{l}11.01 b \\
(+6.14)\end{array}$ & $\begin{array}{c}4.36 \mathrm{a} \\
(+2.64)\end{array}$ & $\begin{array}{l}21.30 \mathrm{a} \\
(-4.97)\end{array}$ & $\begin{array}{c}55.53 a \\
(+0.05)\end{array}$ & $\begin{array}{c}7.90 \mathrm{~b} \\
(+3.11)\end{array}$ \\
\hline $\begin{array}{c}\text { T4-Soil } \\
380 \mathrm{mg} / \mathrm{kg}\end{array}$ & $\begin{array}{l}41.69 c \\
(-0.58)\end{array}$ & $\begin{array}{c}19.36 a \\
(+3.20)\end{array}$ & $\begin{array}{c}\text { 12.13a } \\
(+16.87)\end{array}$ & $4.25 b$ & $\begin{array}{c}18.10 b \\
(-19.24)\end{array}$ & $\begin{array}{c}55.88 a \\
(+0.68)\end{array}$ & $\begin{array}{c}8.60 \mathrm{a} \\
(+12.24)\end{array}$ \\
\hline
\end{tabular}

Notes: Values within a column between treatments, followed by the same letter are not significantly different at $\mathrm{P} \leq 0.05$. Values in parenthesis indicate percentage (\%) increase $(+)$ or $(\%)$ decrease $(-)$ compared to control.

\subsection{Seed Protein, Oil, and Fatty Acids}

A general increasing trend was observed in seed protein percentages compared to control in both foliar applications, while a significant increase in seed protein was found only in soil application T3. In both foliar applications (T1 and T2), where protein increase was not significant, oil percentage also did not show any measurable change. The highest increase in protein observed in T3 was accompanied with significant decrease in oil. The inverse relationship between protein and oil was also evident in T4 where a decrease in protein percentage was accompanied with increase in oil, although the change was not significant. The inverse relationship between protein and oil was previously reported [31] [32]. Protein and oil in the above studies exhibited negative correlation $(r=-0.87)$, while other studies [26] [33] reported increases in both protein and oil with increasing rate of $\mathrm{K}$ fertilizer. The conflicting result could be due to environmental conditions under which soybean was grown or genotype or different rates of $\mathrm{K}$ application.

The increase in protein was also accompanied by increase in $\mathrm{K}$ and $\mathrm{N}$ in leaf tissues. Our findings were in agreement with earlier studies [26] [34]-[37] where they reported an increase in protein with higher K levels. Potassium is directly or indirectly involved in plant protein metabolism [35], with $\mathrm{K}$ crucial in most steps of protein synthesis [35] [38]. Previous research [39] reported enhanced transport of essential amino acids at higher $\mathrm{K}$ fertilizer levels, especially to the developing seeds. Overall, $\mathrm{K}$ application had positive effect on protein, except for high $\mathrm{K}$ soil treatment $\mathrm{T}$ 4, where protein percentage values remained constant in comparison to control, which is in agreement with earlier report [33] which showed a lack of linear correlation between increased $\mathrm{K}$ fertilizer rate and increase in seed constituents.

Potassium (K) application resulted in an increase in palmitic acid in both foliar and soil treatments. Stearic acid was more stable, increasing slightly with T2 and T3 treatments. Foliar treatment increased linoleic acid (C18:2), while decreasing linolenic acid (C18:3) as well as oleic acid (C18:1). Soil application, however, affected seed composition differently by the rate of $\mathrm{K}$ application. Linoleic acid remained stable in soil application, while linolenic acid increased in both soil treatments. The higher rate of soil application T4 resulted in bigger shifts in linolenic and oleic acid percentages. The decrease in oleic acid is in agreement with our earlier study [25] on foliar application of $\mathrm{K}$ and $\mathrm{K}+$ glyphosate on soybean seed composition. In contrast, other authors have reported an increase in oleic acid by K fertilizers [26]. The inconsistency of results may be due to environmental conditions (especially, drought, heat, and soil conditions, greenhouse vs. field experiment), and genotype. Our present research showed that $\mathrm{K}$ application altered seed compositions, overall both the foliar applications and soil application at the lower rate was found to be effective in increasing macronutrients levels in leaf tissue. Soil application at lower rate showed significant increase in linolenic acid and in protein percentages compared to control. Further research is needed to evaluate efficient $\mathrm{K}$ rate application and timing of foliar application to increase desirable seed composition constituents and mineral nutrients without causing high salt accumulations.

\section{Conclusion}

Foliar and soil $\mathrm{K}$ fertilizer application seems to increase concentrations of $\mathrm{K}$ in leaf tissues, and the lower rates 
of $\mathrm{K}$ fertilizer in both applications resulted in increased $\mathrm{N}$ and Fe concentrations. Foliar application increased K, $\mathrm{S}$, Na concentrations in leaf tissues. Seed protein increased, and oil and oleic acid decreased by $\mathrm{K}$ fertilizer. Further research is needed to evaluate the efficiency of $\mathrm{K}$ fertilizer application and timing of application for higher seed composition qualities under field conditions.

\section{Acknowledgements}

We would like to thank Sandra Mosley at USDA-ARS for technical assistance and lab analysis. This research was funded by USDA/Faculty Student Research grant at MVSU. This research was partially funded by United States Department of Agriculture, Agricultural Research Service project number 6402-21220-012-00D. The U.S. Department of Agriculture (USDA) prohibits discrimination in all its programs and activities on the basis of race, color, national origin, age, disability, and where applicable, sex, marital status, familial status, parental status, religion, sexual orientation, genetic information, political beliefs, reprisal, or because all or part of an individual's income is derived from any public assistance program. (Not all prohibited bases apply to all programs.) Persons with disabilities who require alternative means for communication of program information (Braille, large print, audiotape, etc.) should contact USDA's TARGET Center at (202) 720-2600 (voice and TDD). To file a complaint of discrimination, write to USDA, Director, Office of Civil Rights, 1400 Independence Avenue, S.W., Washington DC 20250-9410, or call (800) 795-3272 (voice) or (202) 720-6382 (TDD). USDA is an equal opportunity provider and employer.

\section{References}

[1] (2007) Nutritional \&Health Benefits of Soybean. The Soybean Fact Book, Nutritional \&Health. ASAIM. http://www.asaimsea.com/index.php?language=en\&screenname=_docs_Archive\%20Reference\%20Collection\%7CTh e\%20Soybean\%20Fact\%20Book

[2] Hegstad, H.G. (2008) Nutritional and Health Benefits of Soybean. Soy Protein Quality Evaluation Report. Food and Agriculture Organization on the United Nations. Food and Nutrition, Rome, Paper No. 71.

[3] Chang, E.T., Lee, V.S., Canchola, A.J., Clarke, C.A., Purdie, D.M., Reynolds, P, Anton-Culver, H., Bernstein, L., Deapen, D., Peel, D., Pinder, R., Ross, R.K., Stram, D.O., West, D.W., Wright, W., Ziogas, A. and Horn-Ross, P. L. (2007) Diet and Risk of Ovarian Cancer in the California Teachers Study Cohort. American Journal of Epidemiology, 165, 801-813.

[4] Hasler, C.M. (1998) Scientific Status Summary on Functional Foods: Their Role in Disease Prevention and Health Promotion. Food Technology, 52, 57-62.

[5] Messina, M. (1995) Modern Applications for Ancient Bean: Soybeans and the Prevention and Treatment of Chronic Disease. Journal of Nutrition, 125, 567S-569S.

[6] Messina, M., Gardner, C. and Barnes, S. (2002) Gaining Insight into the Health Effects of Soy but a Long Way Still to Go: Commentary on the Fourth International Symposium on the Role of Soy in Preventing and Treating Chronic Disease. Journal of Nutrition, 132, 547S-551S.

[7] Caragay, A.B. (1992) Cancer-Preventive Foods and Ingredients. Food Technology, 4, 65-68.

[8] Doyle, C., Kushi, L. H., Byers, T., Courneya, K.S., Demark-Wahnefried, W., Grant, B., McTiernan, A., Rock, C.L., Thompson, C., Gansler, T. and Andrews, K.S. (2006) Nutrition and Physical Activity during and after Cancer Treatment: An American Cancer Society Guide for Informed Choices. CA: A Cancer Journal for Clinicians, 56, 323-353. http://dx.doi.org/10.3322/canjclin.56.6.323

[9] Wu, A.H., Yu, M.C., Tseng, C.C. and Pike, M.C. (2008) Epidemiology of Soy Exposures and Breast Cancer Risk. British Journal of Cancer, 98, 9-14. http://dx.doi.org/10.1038/sj.bjc.6604145

[10] Mehdi, S.M., Sarfaraz, M. and Hafeez, M. (2007) Response of Rice Advance Line PB-95 to Potassium Application in Saline-Sodic Soil. Pakistan Journal of Biological Sciences, 10, 2935-2939. http://dx.doi.org/10.3923/pjbs.2007.2935.2939

[11] Tiwari, S.P., Joshi O.P., Vyas, A.K. and Billore, S.D. (2001) Potassium Nutrition in Yield and Quality. 307-320. www.ipipotash.org

[12] Coale, F.J. and Grove, J.H. (1990) Root Distribution and Shoot Development in No-Till Full Season and Double-Crop Soybean. Agronomy Journal, 82, 606-612. http://dx.doi.org/10.2134/agronj1990.00021962008200030034x

[13] Nelson, K.A., Motavalli, P.P. and Nathan, M. (2007) Mobility of Iron and Manganese within Two Citrus Genotypes after Foliar Applications of Sulfate and Manganese. Journal of Plant Nutrition, 30, 1385-1396. 
http://dx.doi.org/10.1080/01904160701555754

[14] Fernandez, F. (2012) Corn, Soybean Showing Signs of Potassium Deficiency. Corn and Soybean Digest Newsletter.

[15] Garcia, R.L. and Hanway, J.J. (1976) Foliar Fertilization of Soybean during the Seed-Filling Period. Agronomy Journal, 68, 653-657. http://dx.doi.org/10.2134/agronj1976.00021962006800040030x

[16] Weir, B. (1998) Foliar Potassium Bumps Cotton Yields: California Researcher Reports Consistent Yield Increases to Foliar-Applied Potassium over a Period of Years in the San Joaquin Valley. Fluid Journal, 6, 10-13.

[17] Dkhil, B.B., Denden, M. and Aboud, S. (2011) Foliar Potassium Fertilization and Its Effect on Growth Yield and Quality of Potato Grown under Loam-Sandy Soil and Semi-Arid Conditions. International Journal of Agricultural Research, 6, 593-600. http://dx.doi.org/10.3923/ijar.2011.593.600

[18] Hiller, L.K. (1995) Foliar Fertilization Bumps Potato Yields in Northwest: Rate and Timing of Application, Plus Host of Other Considerations, Are Critical in Applying Foliars to Potatoes. Fluid Journal, 10, 28-30.

[19] Wilcox, J.R. and Shibles, R.M. (2001) Interrelationship among Seed Quality Attributes in Soybean. Crop Science, 41. 11-14. http://dx.doi.org/10.2135/cropsci2001.41111x

[20] Helrich, K. (1990) Method 988.05. Official Methods of Analysis, 15th Edition, The Association of Official Analytical Chemists Inc., Arlington.

[21] Helrich, K. (1990) Method 920.39. Official Methods of Analysis, 15th Edition, The Association of Official Analytical Chemists Inc., Arlington.

[22] Boydak, E., Alpasian, M., Hayta, M., Gercek, S. and Simsek, M. (2002) Seed Composition of Soybean Grown in the Harran Region of Turkey as Affected by Row Spacing and Irrigation. Journal of Agricultural and Food Chemistry, 50, 4718-4720. http://dx.doi.org/10.1021/jf0255331

[23] Anuradha, K. and Sharma, P.S. (1995) Effect of Moisture Stress and Applied Potassium on Yield and Biochemical Parameters Of Soybean in Vertisols. Journal of Oilseeds Research, 12, 275-278.

[24] Dixit, S.P and Sharma, P.K. (1993) Effect of Lime and Potassium on Yield and Uptake of Nutrients I Wheat (Triticum aestivum)-Soybean (Glycine max)-Linseed (Linum usitatissimum) Cropping Sequence in Acid Alfisol. Indian Journal of Agricultural Science, 63, 333-339.

[25] Pande, M., Goli, M.B., Epps, T. and Bellaloui, N. (2012) Seed Protein, Oil, Fatty Acids, and Mineral Concentration as Affected by Foliar K-Glyphosate Applications in Soybean Cultivars. Agricultural Sciences, 3, 848-853.

[26] Bellaloui, N., Yin, X., Mengistu, A., McClure, A.M., Tyler, D.D. and Reddy, K.N. (2013) Soybean Seed Protein, Oil, Fatty Acids, and Isoflavones Altered by Potassium Fertilizer Rates in the Midsouth. American Journal of Plant Sciences, 4, 976-988. http://dx.doi.org/10.4236/ajps.2013.45121

[27] Mordvedt, J.J. (2001) Calculating Salt Index. Fluid Journal, 9, 8-11.

[28] Parker, M.B. and Boswell, F.C. (1980) Foliar Injury, Nutrient Intake, and Yield of Soybean as Influenced by Foliar Fertilization. Agronomy Journal, 72, 110-113. http://dx.doi.org/10.2134/agronj1980.00021962007200010022x

[29] Mallarino, A.P. and Ul-Haq, M. (1998) Foliar Fertilization of Soybeans. Proceedings of the 28th North Central Extension-Industry Soil Fertility Conference, St. Louis, 11-12 November 1998, 20-26.

[30] Odeleye, F.O., Odeleye, O.M.O. and Animashaun, M.O. (2007) Effects of Nutrient Foliar Spray on Soybean Growth and Yield (Glycine max (L.) Merrill) in South West Nigeria. Notulae Botanicae Horti Agrobotanici Cluj-Napoca, 35, 22-27.

[31] Bellaloui, N., Hanks, J.E., Fisher, D.K. and Mengistu, A. (2009) Soybean Seed Composition Is Influenced by within-Field Variability in Soil Nutrients. Online. Crop Management.

[32] Burton, J.W. (1985) Breeding Soybean for Improved Protein Quantity and Quality. In: Shibles, R., Ed., World Soybean Research Conference III: Proceedings, Westview Press, Boulder, 361-367.

[33] Abbasi, M.K., Tahir, M.M., Azam, W., Abbas, Z. and Rahim, N. (2012) Soybean Yield and Chemical Composition in Response to Phosphorus-Potassium Nutrition in Kashmir. Agronomy Journal, 104, 1476-1484. http://dx.doi.org/10.2134/agronj2011.0379

[34] Bellaloui, N., Bruns, H.A., Gillen, A.M., Abbas, H.K., Zablotowicz, R.M., Mengistu, A. and Paris, R.L. (2010) Soybean Seed Protein, Oil, Fatty Acids, and Mineral Composition as Influenced by Soybean-Corn Rotation. Agricultural Sciences, 1, 102-109. http://dx.doi.org/10.4236/as.2010.13013

[35] Blevins, D.G. (1985) Role of Potassium in Protein Metabolism in Plants. In: Munson, R.D., Ed., Potassium in Agriculture, ASA, CSSA and SSSA, Madison, 413-424.

[36] Pettigrew, W.T. (2008) Potassium Influences on Yield and Quality Production for Maize, Wheat, Soybean and Cotton. Physiologia Plantarum, 133, 670-681. http://dx.doi.org/10.1111/j.1399-3054.2008.01073.x

[37] Magen, H. (1997) IPI Activity in India-Summary Report for 1993-1997: Results from Field Experimentation and De- 
scription of Promotional Activity. International Potash Institute, Horgen, 33.

[38] Evans, H.J. and Wildes, R.A. (1971) Potassium and Its Role in Enzyme Activation. In: Evans, H.J. and Wildes, R.A., Eds., Potassium in Biochemistry and Physiology, International Potash Institute, Berne, 13-19.

[39] Mengel, K., Secer, M. and Koch, K. (1981) Potassium Effect on Protein Formation and Amino Acid Grain. Agronomy Journal, 73, 74-78. http://dx.doi.org/10.2134/agronj1981.00021962007300010018x 